\title{
Meteorological and snow distribution data in the Izas Experimental Catchment (Spanish Pyrenees) from 2011 to 2017
}

\author{
Jesús Revuelto ${ }^{1,2}$, Cesar Azorin-Molina ${ }^{1,3}$, Esteban Alonso-González ${ }^{1}$, Alba Sanmiguel-Vallelado ${ }^{1}$, \\ Francisco Navarro-Serrano $^{1}$, Ibai Rico ${ }^{1,4}$, and Juan Ignacio López-Moreno ${ }^{1}$ \\ ${ }^{1}$ Pyrenean Institute of Ecology, CSIC, Zaragoza, Spain \\ ${ }^{2}$ Météo-France - CNRS, CNRM (UMR3589), Centre d'Etudes de la Neige, Grenoble, France \\ ${ }^{3}$ Regional Climate Group, Department of Earth Sciences, University of Gothenburg, Gothenburg, Sweden \\ ${ }^{4}$ University of the Basque Country. Department of Geography, Prehistory and Archaeology, Vitoria, Spain
}

Correspondence: Jesús Revuelto (jesus.revuelto@meteo.fr)

Received: 20 May 2017 - Discussion started: 1 June 2017

Revised: September 2017 - Accepted: 30 October 2017 - Published: 13 December 2017

\begin{abstract}
This work describes the snow and meteorological data set available for the Izas Experimental Catchment in the Central Spanish Pyrenees, from the 2011 to 2017 snow seasons. The experimental site is located on the southern side of the Pyrenees between 2000 and $2300 \mathrm{~m}$ above sea level, covering an area of 55 ha. The site is a good example of a subalpine environment in which the evolution of snow accumulation and melt are of major importance in many mountain processes. The climatic data set consists of (i) continuous meteorological variables acquired from an automatic weather station (AWS), (ii) detailed information on snow depth distribution collected with a terrestrial laser scanner (TLS, lidar technology) for certain dates across the snow season (between three and six TLS surveys per snow season) and (iii) time-lapse images showing the evolution of the snow-covered area (SCA). The meteorological variables acquired at the AWS are precipitation, air temperature, incoming and reflected solar radiation, infrared surface temperature, relative humidity, wind speed and direction, atmospheric air pressure, surface temperature (snow or soil surface), and soil temperature; all were taken at 10 min intervals. Snow depth distribution was measured during 23 field campaigns using a TLS, and daily information on the SCA was also retrieved from time-lapse photography. The data set (https://doi.org/10.5281/zenodo.848277) is valuable since it provides high-spatial-resolution information on the snow depth and snow cover, which is particularly useful when combined with meteorological variables to simulate snow energy and mass balance. This information has already been analyzed in various scientific studies on snow pack dynamics and its interaction with the local climatology or topographical characteristics. However, the database generated has great potential for understanding other environmental processes from a hydrometeorological or ecological perspective in which snow dynamics play a determinant role.
\end{abstract}

\section{Introduction}

Snowpack distribution and its temporal evolution have a marked influence on many mountain processes. These include erosion rates and sediment transport (Colbeck et al., 1979; Lana-Renault et al., 2011) and geomorphological and glaciological processes (López-Moreno et al., 2017; Serrano et al., 2001). Phenological cycles (Liston, 1999; Wipf et al., 2009) are directly controlled by the evolution of snow cover over time. Conversely, snowmelt dynamics are also of major importance from a hydrological perspective since onesixth of the Earth's total population depends on the water storage in mountain river headwaters (Barnett et al., 2005). In downstream areas exposed to extreme climatic conditions, the snowmelt runoff from mountain areas becomes a key element (Viviroli et al., 2007), especially in zones affected by 
water shortages. This is the case of semiarid regions, like the Mediterranean area, which are characterized by an irregular climate with long drought periods (Vicente-Serrano, 2006), and therefore are highly dependent on water stored in mountain areas, such as the Pyrenees (López-Moreno, 2005; López-Moreno et al., 2008).

The Pyrenees are a midlatitude mountain range, with significant snowfalls in the high-elevation areas throughout the year. During the spring, Pyrenean river discharges depend on the snowmelt timing, with approximately $40 \%$ of spring runoff being directly attributable to snow (López-Moreno and García-Ruiz, 2004). Thus, snow accumulation has a heavy influence on Pyrenean headwaters. This dependence is mostly due to the generally continuous snow cover from November to April above $2000 \mathrm{~m}$ above sea level (a.s.l.) (Alvera and Garcia-Ruiz, 2000; García-Ruiz et al., 1986; López-Moreno et al., 2002) and, therefore, the study of the snowpack at high elevations in the Pyrenees is crucial for understanding and managing mountain river discharges (López-Moreno, 2005), especially in the scenario of global climate change (García-Ruiz et al., 2011). However, continuous snow observations above $2000 \mathrm{~m}$ a.s.l. are scarce in this mountain range since most only have information from 1600 to $2000 \mathrm{~m}$ a.s.l. and those that are available only cover short time spans. Therefore, well-established study areas at high elevations with continuous measurements of meteorological variables and snowpack distribution are required in the Pyrenees.

This paper presents the recently acquired data set of meteorological and snowpack variables obtained from a small experimental catchment on the southern face of the Pyrenees. Although meteorological and hydrological data are available from previous years (some variables have been measured since the late 1980s; Alvera and Garcia-Ruiz, 2000), we present data from the 2011/12 to 2016/17 snow seasons, as data series provide higher quality and continuity, and they also match in situ observations of snow depth and snow cover. The data set consists of (i) continuous meteorological variables acquired from an automatic weather station (AWS), (ii) detailed information on snow depth distribution collected with a terrestrial laser scanner (TLS, lidar technology) for certain dates across the snow season (between two and six TLS surveys per snow season) and (iii) time-lapse images showing the snow-covered area (SCA) evolution. Some years of this data set have already been used to study the topographic control on snow depth distribution (Revuelto et al., 2014b), the spatial variability in snowpack at different distances (López-Moreno et al., 2012) or to investigate how detailed snowpack simulation could be improved by including snow distribution information (Revuelto et al., 2016a, b).

The paper is structured as follows: Sect. 2 describes the study area characteristics; Sect. 3 presents meteorological data acquired from the AWS with a general description of the observed climatology; Sect. 4 describes the distributed measurements on snow depth distribution from the TLS and the SCA derived from time-lapse images; Sect. 5 concludes with information for downloading the database; and finally Sect. 6 summarizes all information available and the potential application of the database.

\section{Study area characteristics and climatology}

\subsection{The Pyrenees}

The Pyrenees lie on the northeastern border of the Iberian Peninsula (Fig. 1) and form an orographic barrier between the north and south faces. Due to this, progressively higher aridity is found toward the south as the mountain range blocks humid air masses from the Atlantic (López-Moreno and Vicente-Serrano, 2007; VicenteSerrano, 2005). Thus, the natural barrier directly influences precipitation, leading to areas above $2000 \mathrm{~m}$ a.s.l. receiving about $2000 \mathrm{~mm}$ year $^{-1}$, increasing to $2500 \mathrm{~mm} \mathrm{year}^{-1}$ in the highest divides of the mountain range and rapidly decreasing to $600-800 \mathrm{~mm}^{\text {year }}{ }^{-1}$ in low-elevation areas on the southern side (García-Ruiz, et al., 2001).

Another distinct feature of the Pyrenees is their location between two water masses with contrasting conditions, i.e., the Atlantic Ocean is on the west side, while the Mediterranean Sea lies in the east. This position between both water masses causes a climatic transition from oceanic to mediterranean conditions in the east. During autumn, fronts approaching from the Atlantic bring the highest monthly averages of precipitation in the western observatories, with their total contribution accounting for $40 \%$ of total annual precipitation in this area (Creus-Novau, 1983). Conversely, spring and summer storms mostly affect the eastern areas of the Pyrenees, promoted by the development of zones in which sea breezes and local winds converge to initiate deep moist convection along the eastern fringe of the Iberian Mediterranean area (Azorin-Molina et al., 2015). Therefore, Pyrenean observatories in the east record a large number of convective events, i.e up to $32 \%$ of total annual precipitation in eastern valleys, but dropping below $16 \%$ of annual precipitation in western valleys (Cuadrat et al., 2007). In early winter, the arrival of fronts from the northwest and west are the most frequent, leading to the highest snow accumulation found in the western Pyrenees (Navarro-Serrano and López-Moreno, 2017). The Azores high, which usually affects the Iberian Peninsula at certain times in the winter, gives rise to relatively long periods with no snow accumulation in this season. Subsequently, in spring, snow accumulation is associated with southwesterly advections, which lead to heavy snow accumulations in the western Pyrenees (Revuelto et al., 2012). Snow remains for long periods above $1600 \mathrm{~m}$ a.s.l., between November and April (López-Moreno and Nogués-Bravo, 2006).

Similar to precipitation, air temperature is influenced by the Atlantic-Mediterranean transitions, but elevation plays a major role in its distribution. For instance, the lower annual 

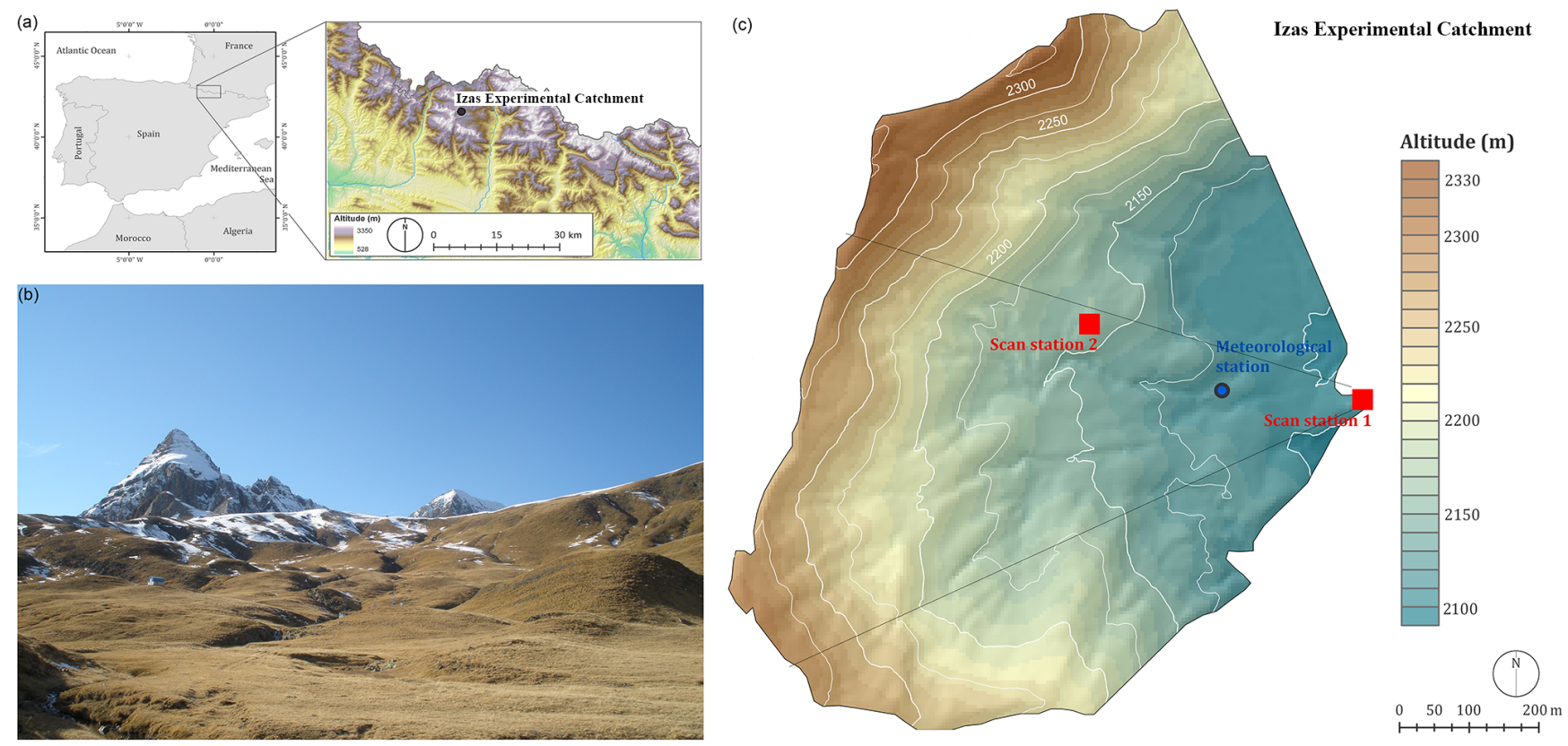

Figure 1. The Izas Experimental Catchment study site. Panel (a) shows the location of the study site. Panel (b) shows an overview of the catchment with marginal snow presence. The right map (c) shows the topographic characteristics of the catchment and the location of the TLS scanning positions (Scan stations), the meteorological station and the field of view of the time-lapse camera (continuous lines from Scan station 1).

thermal amplitude observed in the western Pyrenees is because of the proximity of the ocean (Cuadrat et al., 2007). As a general tendency in the Central Pyrenees, the annual $0{ }^{\circ} \mathrm{C}$ isotherms lie between 2700 and $2900 \mathrm{~m}$ a.s.l. (del Barrio et al., 1990; Chueca, 1993).

Additionally the Pyrenees exhibit a high interannual variability in air temperature and precipitation, which makes the annual snow accumulation very uncertain (López-Moreno, 2005). This variability is influenced by the interannual variability in atmospheric circulation, with a decrease in snow accumulation weather types being identified under positive North Atlantic Oscillation (NAO) phases (López-Moreno and Vicente-Serrano, 2007). As observed with precipitation, snow accumulation correlates to Atlantic-Mediterranean proximity and distance from the main divide of the mountain range (Revuelto et al., 2012), and it is strongly dependent on the fluctuations of the $0^{\circ} \mathrm{C}$ isotherm during winter and spring. This high climatic variability is also the cause of large interannual variability in total snow accumulation and its temporal distribution across the snow season (LópezMoreno, 2005).

\subsection{The Izas Experimental Catchment}

The Izas Experimental Catchment $\left(42^{\circ} 44^{\prime} \mathrm{N}, 0^{\circ} 25^{\prime} \mathrm{W}\right)$ has a surface area of 33 ha, but snow depth information covers a total of 55 ha, with elevations ranging between 2075 and $2325 \mathrm{~m}$ a.s.l. This area is close to the main divide of the Pyrenees in the headwaters of the Gállego River, near the
Spain-France border (Fig. 1). The Izas Experimental Catchment exemplifies the general characteristics of subalpine areas of the Pyrenees. In this environment, snowpack dynamics are of major importance throughout the year. Thus, the atmosphere-snowpack interactions observed at this experimental site will enable a better understanding of many processes in subalpine areas.

The mean annual precipitation is $2000 \mathrm{~mm}$, and snow accounts for approximately $50 \%$ of total precipitation (Anderton et al., 2004). For an average of 130 days each year the mean daily air temperature is below $0{ }^{\circ} \mathrm{C}$, with a mean annual air temperature of $3{ }^{\circ} \mathrm{C}$ (del Barrio et al., 1997). Snow covers a high percentage of the catchment from November to the end of May (López-Moreno et al., 2010). Lithology shows limestones and sandstones of the Cretaceous period, and limestones of the Paleocene, much more resistant to erosion. The zonal vegetation type corresponds to a high mountain steppe, mainly covered by bunch grasses, namely Festuca eskia, Nardus stricta, Trifolium alpinum, Plantago alpine and Carex sempervirens. Rocky outcrops dominate the upper and steeper slopes (less than $15 \%$ of the study area). There are no trees present in the study area. The catchment is predominantly east-facing, with some areas also facing north or south. The mean slope of the catchment is $16^{\circ}$ (López-Moreno et al., 2012), with the topographic characteristics displaying the typical high spatial heterogeneity of subalpine areas, with flat concave and convex areas. 

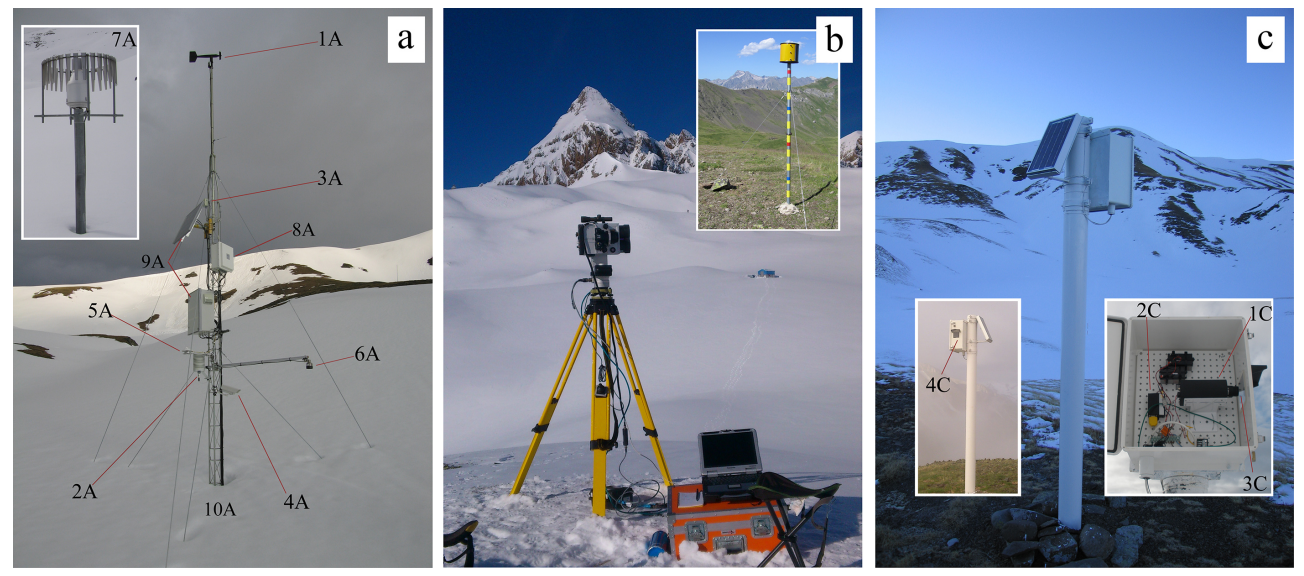

Figure 2. Pictures of the experimental site equipment. (a) AWS sensors. 1A: Young wind sensor; 2A: radiation shield with HMP 155 humidity and temperature probe; 3A: BP1 air pressure recorder; 4A: IR100 infrared remote temperature sensor; 5A: CMA6 Kipp \& Zonen albedometer; 6A: SR50A range sensor; 7A: Geonor T-200B with wind shield; 8A: CR3000 data logger and modem; 9A: solar panel and battery; 10A: Campbell Scientific 107 ground temperature probes. (b) RIEGL LPM-321 TLS mounted on the tripod during an acquisition campaign. The upper-right part shows one of the 12 fixed reflective targets fixed on the terrain. (c) Campbell CC640 camera mounted in the metal structure with $1 \mathrm{C}$ : digital camera inside the enclosure house; $2 \mathrm{C}$ : modem; $3 \mathrm{C}$ : protection glass of the digital camera; and 4C: frontal view of the camera and its structure.

\section{Meteorological data}

The study site is equipped with an AWS located in the lower elevation of the catchment $\left(42^{\circ} 44^{\prime} 33.65^{\prime \prime} \mathrm{N}, 0^{\circ} 25^{\prime} 8.83^{\prime \prime} \mathrm{W}\right.$, $2113 \mathrm{~m}$ a.s.l.; Fig. 1), located in a flat open area with sparse vegetation (mountain pastures). The AWS measures wind speed and direction, atmospheric air temperature, relative humidity and air pressure, soil temperature for $0,5,10$, and $20 \mathrm{~cm}$, temperature of the surface close to the AWS (snow or soil, depending on whether snow is present or not), global and reflected solar irradiance, snow depth, and precipitation (the precipitation gauge is located at $15 \mathrm{~m}$ from the AWS tower) (see Fig. 2). Information on the main atmospheric variables has been recorded since the end of 2011 (AWS installed in November 2011). Therefore, data availability covers five complete snow seasons. Since the station is located in the lower elevation of the catchment and despite air temperature lapse rate with elevation, the AWS records serve to describe the evolution of atmospheric variables occurring at the Izas Experimental Catchment.

The data acquisition system consists of a Campbell Scientific CR3000 data logger that samples each instrument and stores data at $10 \mathrm{~min}$ time intervals. All data are transmitted via modem to the Pyrenean Institute of Ecology where automatic quality-control checks are applied to remove outliers. Data gaps are rare for almost all variables and, therefore, instead of gap filling with interpolation methods, only measured data are available. However, some variables had long data gaps and certain periods have been discarded from further analysis. This is the case of precipitation for the first three snow seasons, which were useless because of the length of data gaps.
Since the main application of the data collected by the AWS is to assess the evolution of snow cover in the study area, in the following subsections we focus our analyses on the accumulation and melt periods, i.e., accumulation (January, February and March; JFM) and melt (April, May and June; AMJ). Annual values observed during a whole snow season are also presented for each subsection.

\subsection{Wind speed and direction}

The AWS is equipped with a Young wind monitor - Alpine model (Young Company, 2010), placed at the highest point of the meteorological tower ( $8 \mathrm{~m}$ above the ground). The Pyrenees are commonly affected by strong westerly to northerly winds as shown in the wind roses displayed in Fig. 3. With the exception of south winds that mainly occur during the melt period, westerly to northerly winds dominate. Additionally, the most frequently moderate to strong winds come from the northwest.

\subsection{Air temperature, relative humidity and atmospheric air pressure}

Air temperature and relative humidity were measured with the HMP155 Vaisala sensor (Vaisala Company, 2012), and atmospheric air pressure was recorded with the BP1 sensor from ADCON Telemetry (ADCON Telemetry Company, 2015). The HMP 155 humidity and temperature probe was placed inside a standard radiation shield at $3.2 \mathrm{~m}$ from the ground in order to prevent the snowpack from eventually covering the sensors. 

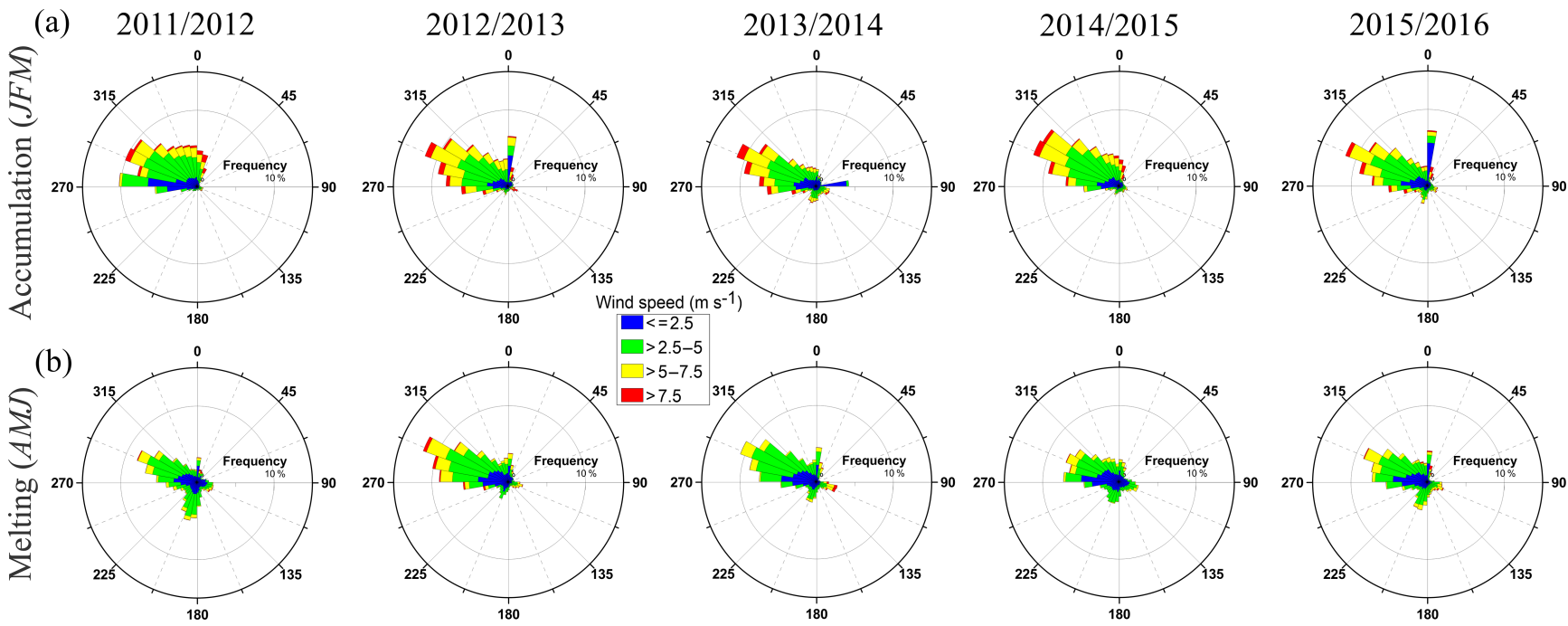

Figure 3. Wind roses showing the frequency (\%) of wind speed and direction observed in the AWS for accumulation (a) and melt (b) snow seasons.

Table 1. Mean and standard deviation of air temperature for the five snow seasons for the annual, accumulation and melt periods. Also shown are maximum and minimum air temperatures for each period of the snow seasons.

\begin{tabular}{rlrrrrrr}
\hline & \multicolumn{5}{c}{ Air temperature $\left({ }^{\circ} \mathrm{C}\right)$} \\
\cline { 3 - 8 } & & $2011 / 12$ & $2012 / 13$ & $2013 / 14$ & $2014 / 15$ & $2015 / 16$ & $2016 / 17$ \\
\hline \multirow{3}{*}{ Mean } & Annual & $5.13 \pm 7.73$ & $3.50 \pm 6.88$ & $4.17 \pm 6.11$ & $5.26 \pm 7.02$ & $5.08 \pm 6.69$ & Nan \\
& Accumulation & $-1.15 \pm 5.69$ & $-2.78 \pm 4.57$ & $-1.71 \pm 3.44$ & $-1.65 \pm 4.87$ & $-1.66 \pm 3.69$ & $-0.56 \pm 4.20$ \\
& Melting & $5.80 \pm 6.60$ & $2.79 \pm 4.79$ & $5.51 \pm 4.07$ & $7.23 \pm 4.86$ & $4.45 \pm 5.12$ & $7.58 \pm 6.00$ \\
\hline \multirow{3}{*}{ Max } & Annual & 25.87 & 20.85 & 21.42 & 24.07 & 24.23 & Nan \\
& Accumulation & 7.89 & 10.69 & 10.20 & 10.98 & 11.62 & 11.39 \\
& Melting & 18.29 & 17.13 & 18.32 & 23.07 & 19.26 & 22.51 \\
\hline \multirow{3}{*}{ Min } & Annual & -18.51 & -15.26 & -11.35 & -15.24 & -11.78 & Nan \\
& Accumulation & -18.51 & -15.26 & -11.35 & -15.24 & -11.78 & -14.97 \\
& Melting & -9.33 & -9.04 & -3.71 & -4.76 & -8.20 & -8.33 \\
\hline
\end{tabular}

Nan: no data observed during the period.

Over the six snow seasons analyzed, the mean annual air temperature ranged between $5.26^{\circ} \mathrm{C}(2014 / 15)$ and $3.51^{\circ} \mathrm{C}$ $(2012 / 13)$, with an average value of $4.59^{\circ} \mathrm{C}$. The mean air temperature in the accumulation period ranged from $-2.78^{\circ} \mathrm{C}(2012 / 13)$ to $-0.56{ }^{\circ} \mathrm{C}(2016 / 17)$, with an average value of $-1.59^{\circ} \mathrm{C}$ for the whole study period. Finally, the melt period returned a mean value of $5.56^{\circ} \mathrm{C}$ ranging from $2.79^{\circ} \mathrm{C}(2012 / 13)$ to $7.58^{\circ} \mathrm{C}(2016 / 17)$. Table 1 shows that the 2012/13 snow season was the coldest in the study period. Figure 4 depicts the temporal evolution of air temperature and other variables observed in the AWS from 2011 to 2016. Thus, this figure shows the control points for air temperature on the ground and the surface temperature.

The relative air humidity and the atmospheric air pressure are shown in Tables 2 and 3, respectively. The mean annual value of the relative humidity for the five seasons is $65 \%$, with $67 \%$ during the accumulation period and $66 \%$ during the melt. Similarly, atmospheric air pressure has a mean annual value of 791 mbar, with 787 mbar for the accumulation period and 792 mbar for the melt.

\subsection{Ground temperature}

On 22 November 2012 four Campbell Scientific 107 temperature probes (Campbell Scientific Ltd, 2012) were installed in the AWS to measure ground temperature at different depths. One sensor was located in the atmosphereground interface (slightly buried, $0 \mathrm{~cm}$ depth), while the other three were placed at depths of 5,10 and $20 \mathrm{~cm}$. Table 4 and Fig. 4 show the average values of ground temperatures and the temporal evolution of ground temperature. Data are lacking from August 2016 onwards because tem- 

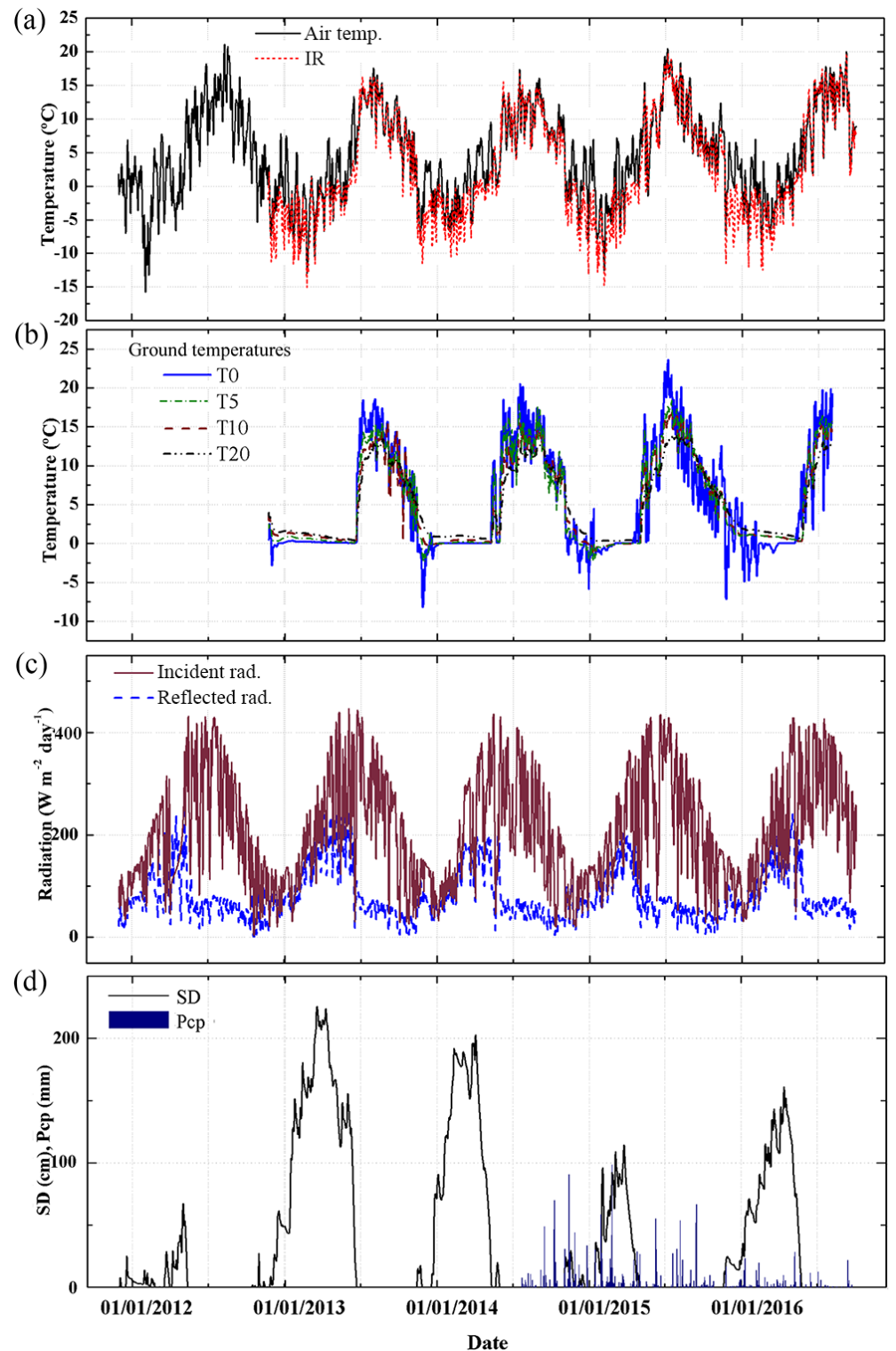

Figure 4. Temporal evolution of meteorological variables from 2011 to 2016 . From top to bottom are air temperature and surface temperature (from the IR sensor); ground temperature for the four depths; global (Incident) and reflected solar irradiance; punctual snow depth (SD); and daily accumulated precipitation (Pcp) (sum of solid and liquid).

Table 2. Mean and standard deviation of relative humidity for the five snow seasons for the annual, accumulation and melt periods.

\begin{tabular}{lrrrrrr}
\hline & \multicolumn{7}{c}{ Relative air humidity (\%) } \\
\cline { 2 - 7 } & $2011 / 12$ & $2012 / 13$ & $2013 / 14$ & $2014 / 15$ & $2015 / 16$ & $2016 / 17$ \\
\hline Annual & $59.9 \pm 18.9$ & $70.1 \pm 17.1$ & $68.8 \pm 17.3$ & $64.8 \pm 19.2$ & $65.9 \pm 18.5$ & Nan \\
Accumulation & $67.1 \pm 18.1$ & $70.5 \pm 19.3$ & $72.7 \pm 15.8$ & $62.8 \pm 22.2$ & $71.3 \pm 18.3$ & $61.0 \pm 20.8$ \\
Melting & $57.1 \pm 15.2$ & $74.4 \pm 14.5$ & $68.7 \pm 15.9$ & $63.9 \pm 15.8$ & $69.9 \pm 14.1$ & $62.9 \pm 15.65$ \\
\hline
\end{tabular}

Nan: no data observed during the period. 
Table 3. Mean and standard deviation of atmospheric air pressure for the five snow seasons for the annual, accumulation and melt periods.

\begin{tabular}{lrrrrrr}
\hline & \multicolumn{7}{c}{ Atmospheric air pressure (mbar) } \\
\cline { 2 - 7 } & $2011 / 12$ & $2012 / 13$ & $2013 / 14$ & $2014 / 15$ & $2015 / 16$ & $2016 / 17$ \\
\hline Annual & $794.5 \pm 5.9$ & $790.7 \pm 7.7$ & $791.3 \pm 6.5$ & $792.4 \pm 6.9$ & $791.8 \pm 7.1$ & Nan \\
Accumulation & $790.9 \pm 7.2$ & $784.7 \pm 8.3$ & $786.4 \pm 6.9$ & $789.7 \pm 9.3$ & $786.8 \pm 7.9$ & $788.5 \pm 5.5$ \\
Melting & $797.1 \pm 3.6$ & $790.9 \pm 6.6$ & $791.8 \pm 4.6$ & $794.2 \pm 4.4$ & $788.9 \pm 5.4$ & $791.5 \pm 5.0$ \\
\hline
\end{tabular}

Nan: no data observed during the period.

Table 4. Mean and standard deviation ground temperature for different depths for the five snow seasons for the annual, accumulation and melt periods.

\begin{tabular}{|c|c|c|c|c|c|c|c|}
\hline & \multirow[b]{2}{*}{$\begin{array}{r}\text { Depth } \\
(\mathrm{cm})\end{array}$} & \multicolumn{6}{|c|}{ Ground temperatures $\left({ }^{\circ} \mathrm{C}\right)$} \\
\hline & & $2011 / 12$ & $2012 / 13$ & $2013 / 14$ & $2014 / 15$ & $2015 / 16$ & $2016 / 17$ \\
\hline \multirow{4}{*}{ Annual } & 0 & Nan & $4.60 \pm 6.71$ & $5.13 \pm 6.45$ & $5.98 \pm 7.02$ & $4.24 \pm 6.02$ & Nan \\
\hline & 5 & Nan & $4.35 \pm 5.67$ & $5.61 \pm 6.52$ & $6.06 \pm 5.52$ & $4.66 \pm 5.12$ & Nan \\
\hline & 10 & Nan & $4.38 \pm 5.19$ & $5.07 \pm 5.46$ & $5.99 \pm 6.09$ & $4.55 \pm 4.87$ & Nan \\
\hline & 20 & Nan & $4.26 \pm 4.66$ & $5.01 \pm 4.62$ & $5.08 \pm 3.26$ & $4.51 \pm 3.88$ & Nan \\
\hline \multirow{4}{*}{ Acc. } & 0 & Nan & $0,22 \pm 0,05$ & $0.03 \pm 0.04$ & $-0.26 \pm 0.87$ & $-0.66 \pm 1.13$ & Nan \\
\hline & 5 & Nan & $0,69 \pm 0.12$ & $0.11 \pm 0.08$ & $-0.39 \pm 0.54$ & $0.99 \pm 0.10$ & Nan \\
\hline & 10 & Nan & $1.10 \pm 0.16$ & $0.31 \pm 0.18$ & $-0.27 \pm 0.23$ & $0.98 \pm 0.11$ & Nan \\
\hline & 20 & Nan & $1.34 \pm 0.19$ & $0.94 \pm 0.06$ & $0.39 \pm 0.08$ & $1.57 \pm 0.17$ & Nan \\
\hline \multirow{4}{*}{ Melting } & 0 & Nan & $1.21 \pm 3.49$ & $5.53 \pm 6.41$ & $7.87 \pm 6.41$ & $4.57 \pm 5.46$ & Nan \\
\hline & 5 & Nan & $1.04 \pm 2.45$ & $5.19 \pm 6.08$ & $7.03 \pm 5.71$ & $4.43 \pm 5.09$ & Nan \\
\hline & 10 & Nan & $1.06 \pm 1.78$ & $4.15 \pm 4.68$ & $6.46 \pm 5.32$ & $4.15 \pm 4.79$ & Nan \\
\hline & 20 & Nan & $1.04 \pm 1.36$ & $3.46 \pm 3.49$ & $5.35 \pm 4.15$ & $3.50 \pm 3.47$ & Nan \\
\hline
\end{tabular}

Nan: no data observed during the period.

perature probes were damaged by cows. The average values during the period with information for the $0,5,10$ and $20 \mathrm{~cm}$ depths are, respectively, $5.26 \pm 6.22,4.97,4.93 \pm 6.17$ and $4.89 \pm 4.56^{\circ} \mathrm{C}$.

The temporal evolution of air and ground temperatures depicts the impact of the snowpack on ground energy dynamics. The snowpack shelters the ground from the high temporal variability in air temperature. Therefore, the daily variability in ground temperatures is significantly lower. Furthermore, the different ground temperatures tend to reach $0^{\circ} \mathrm{C}$ while snow covers the ground, i.e., the typical soil-snow interface temperature.

\subsection{Surface temperature}

Together with the installation of the ground temperature sensors, an IR100 infrared remote temperature sensor (Campbell Scientific Ltd, 2015) was also set up to measure surface temperature of near-target ground or snow. Table 5 shows the average land surface temperatures. The mean annual surface temperature is $2.56^{\circ} \mathrm{C}$, with a mean value of $-4.58^{\circ} \mathrm{C}$ during the accumulation period and $3.94{ }^{\circ} \mathrm{C}$ during the melt period.
The infrared remote sensor shows the tendency of the snow surface to cool faster than soil. During winter and spring, while snow is present on the ground, the differences between air and surface temperature are more marked, with surface temperatures always observed to be lower (see the occurrence of snow below the AWS when lower surface temperatures are observed in Fig. 4). This plainly exemplifies the higher energy irradiance of snow when compared to snowfree soils.

\subsection{Global and reflected solar irradiance}

The AWS also obtains information on the global and reflected solar irradiance with a CMA 6 Kipp \& Zonen albedometer (Kipp \& Zonen B. V., 2016) placed at $3.4 \mathrm{~m}$ height. Figure 4 shows the daily evolution of the values recorded and how these are interrelated, with the reflected radiation increasing at the same time as the incident. The average values of these variables are presented in Table 6 . For the whole period, the average values of the incident radiation are $207.97 \mathrm{~W} \mathrm{~m}^{-2}$ day, taking complete snow seasons into account, $164.73 \mathrm{~m}^{-2}$ day for accumulation and $280.95 \mathrm{~m}^{-2}$ day 
Table 5. Mean surface temperature from the infrared sensor for the five snow seasons for the annual, accumulation and melt periods.

\begin{tabular}{llrrrrr}
\hline & \multicolumn{5}{c}{ Surface temperature $\left({ }^{\circ} \mathrm{C}\right)$} \\
\cline { 2 - 7 } & $2011 / 12$ & $2012 / 13$ & $2013 / 14$ & $2014 / 15$ & $2015 / 16$ & $2016 / 17$ \\
\hline Annual & Nan & $1.29 \pm 7.83$ & $2.44 \pm 7.06$ & $3.26 \pm 8.14$ & $3.26 \pm 7.71$ & Nan \\
Accumulation & Nan & $-5.38 \pm 3.58$ & $-4.18 \pm 2.65$ & $-5.36 \pm 3.61$ & $-4.32 \pm 2.99$ & $-3.68 \pm 3.58$ \\
Melting & Nan & $-0.09 \pm 3.44$ & $3.75 \pm 5.16$ & $5.95 \pm 6.02$ & $3.47 \pm 5.96$ & $6.64 \pm 6.67$ \\
\hline
\end{tabular}

Nan: no data observed during the period.

Table 6. Mean global and reflected radiation for the five snow seasons for the annual, accumulation and melt periods.

\begin{tabular}{llrrrrrr}
\hline & & \multicolumn{5}{c}{ Radiation $\left(\mathrm{W} \mathrm{m}^{-2}\right.$ day $)$} \\
\cline { 3 - 8 } & & $2011 / 12$ & $2012 / 13$ & $2013 / 14$ & $2014 / 15$ & $2015 / 16$ & $2016 / 17$ \\
\hline \multirow{2}{*}{ Annual } & Global & $219.48 \pm 110.60$ & $205.36 \pm 114.50$ & $196.64 \pm 110.49$ & $207.63 \pm 116.50$ & $211.03 \pm 113.95$ & Nan \\
& Reflected & $82.87 \pm 49.60$ & $96.20 \pm 64.92$ & $79.35 \pm 52.78$ & $76.34 \pm 64.90$ & $83.61 \pm 53.76$ & Nan \\
\hline \multirow{2}{*}{ Acc. } & Global & $181.09 \pm 68.18$ & $154.83 \pm 67.30$ & $150.04 \pm 84.02$ & $166.97 \pm 65.80$ & $152.83 \pm 83.18$ & $182.64 \pm 85.36$ \\
& Reflected & $99.14 \pm 40.34$ & $117.04 \pm 44.35$ & $108.50 \pm 47.43$ & $114.24 \pm 44.35$ & $108.94 \pm 48.59$ & $110.29 \pm 41.13$ \\
\hline \multirow{2}{*}{ Melting } & Global & $245.37 \pm 120.56$ & $289.59 \pm 114.10$ & $283.33 \pm 102.80$ & $287.65 \pm 117.15$ & $278.71 \pm 114.37$ & $301.07 \pm 107.57$ \\
& Reflected & $103.11 \pm 67.15$ & $169.56 \pm 60.28$ & $114.83 \pm 61.10$ & $90.51 \pm 60.28$ & $120.06 \pm 67.30$ & $104.28 \pm 66.7$ \\
\hline
\end{tabular}

Nan: no data observed during the period.

Table 7. Accumulated precipitation (liquid and solid) for snow seasons with observations available. Average snow depth values for accumulation and melt periods for the five snow seasons.

\begin{tabular}{rlrrrrrr}
\hline & & \multicolumn{5}{c}{ Accumulated total precipitation $(\mathrm{mm})$} \\
\cline { 3 - 8 } & & $2011 / 12$ & $2012 / 13$ & $2013 / 14$ & $2014 / 15$ & $2015 / 16$ & $2016 / 17$ \\
\hline \multirow{2}{*}{ Ann } & Pcp $(\mathrm{mm})$ & Nan & Nan & Nan & 1572 & 411 & Nan \\
\hline \multirow{2}{*}{ Acc. } & SD $(\mathrm{cm})$ & $14.74 \pm 14.60$ & $145.61 \pm 52.3$ & $148.54 \pm 41.60$ & $55.90 \pm 36.50$ & $81.42 \pm 31.67$ & $114.44 \pm 73.80$ \\
& Pcp $(\mathrm{mm})$ & Nan & Nan & Nan & 454.35 & 147.22 & 82.38 \\
\hline \multirow{2}{*}{ Mlt. } & SD (cm) & $1.60 \pm 1.57$ & $131.42 \pm 64.64$ & $51.57 \pm 64.95$ & $12.70 \pm 22.24$ & $64.30 \pm 59.85$ & $25.14 \pm 32.22$ \\
& Pcp (mm) & Nan & Nan & Nan & 249.61 & 121.05 & 162.51 \\
\hline
\end{tabular}

Nan: no data observed during the period.

for all melt periods. Similarly, the reflected radiation average values are $83.67 \mathrm{~m}^{-2}$ day for entire snow seasons, $109.69 \mathrm{~m}^{-2}$ day for the accumulation and $117.06 \mathrm{~m}^{-2}$ day for melt periods.

Similar to ground and surface temperatures, the radiation reflected is heavily influenced by the presence of snow. When snow covers the ground, the sensor shows higher values of reflected radiation in comparison with snow-free periods (Fig. 4).

\subsection{Snow depth and precipitation}

The AWS is also equipped with a Campbell SR50A sonic ranging sensor (Campbell Scientific Ltd, 2011). For the sake of simplicity we will refer to it as a snow depth sensor since it is used for measuring the changing distance between the surface and the sensor (the sensor is placed $2.64 \mathrm{~m}$ from the ground, and the snow depth is obtained by subtracting this value from the observed distance). This sensor worked uninterruptedly during the study period and provided a good record of the snow depth evolution in the Izas Experimental Catchment. Therefore, the information on the snow depth can be used as a reference for other observations of snowpack evolution. The average values for the whole study period are $93.4 \mathrm{~cm}$ for the accumulation period and $47.8 \mathrm{~cm}$ for the melt period (Table 7 shows the seasonal values). The temporal evolution of the snow depth is shown in Fig. 4.

In addition, Fig. 4 shows the precipitation values for the period with data in the precipitation gauge (from the end of July 2014). The sensor installed is a Geonor T-200B with a wind shield (Geonor A/S, 2010), which continuously weighs the accumulated precipitation (liquid and solid). The height 
of the gauge orifice is $3.25 \mathrm{~m}$ ( $2.5 \mathrm{~m}$ metal pedestal plus the height of the T-200B inlet). The precipitation accumulated over a certain period was calculated by subtracting final and initial weighted values. Table 7 includes the accumulated precipitation for the whole snow year and also during the accumulation and melt periods.

\section{Information on snow distribution}

\subsection{TLS acquisitions of snow depth distribution}

During the five snow seasons presented here, three to six TLS surveys were carried out each year in the Izas Experimental Catchment. TLSs are devices using lidar technology, a remote sensing method to obtain the distance between a target area and the device. During a TLS data acquisition, the device measures the distance of some hundreds of thousands of points within the area defined by the operator, creating a cloud of data points representing the topography of the target surface. The device used in this study is a long-range TLS (RIEGL LPM-321 (Fig. 2), RIEGL Laser Measurements, 2010). The technical characteristics of this model include (i) light pulses of $905 \mathrm{~nm}$ wavelength (near infrared), appropriate for acquiring data from snow cover (Prokop, 2008); (ii) a minimum angular step width of $0.018^{\circ}$; (iii) a laser beam divergence of $0.046^{\circ}$; and (iv) a maximum working distance of $6000 \mathrm{~m}$. In order to reduce topographic shadowing (note that terrain topography limits the line of sight of the TLS), two scanning positions (Scan station in Fig. 1) were established within the study site (Fig. 1). Also fixed on the terrain, were 12 reflected targets (Fig. 2). The location of these targets was acquired on each TLS acquisition date since this information is used in the post-processing phase for comparing the point clouds acquired on different dates. The protocol for obtaining the information in the field and the methodology for generating the snow depth distribution maps for the different TLS survey dates is fully explained in Revuelto et al. (2014a). The method is mainly based on calculating the elevation difference between the point clouds obtained on different dates with and without snow cover across the study area. The final products are snow depth distribution maps with a grid size of $1 \mathrm{~m} \times 1 \mathrm{~m}$, with a mean absolute error of $0.07 \mathrm{~m}$ in the snow depth values (Revuelto et al., 2014a).

Figure 5 shows the snow depth maps obtained for the 2012/13 snow season. The information for this snow season is presented because six TLS surveys were completed. Furthermore, the accumulated snow depths were significant and thus provide an interesting example of snowpack evolution over time. These maps show the high spatial variability in the snowpack within the study area, with marked changes in the snow depth distribution within short distances. It was also observed how high-accumulation areas had large accumulations during the whole snow season, with a thick snowpack
Table 8. Observed mean and maximum snow depth values, snowcovered area (SCA, \% of the total area covered by the TLS), and coefficient of variation for the observed snow distribution on the TLS survey dates.

\begin{tabular}{|c|c|c|c|c|c|}
\hline $\begin{array}{l}\text { Snow } \\
\text { season }\end{array}$ & Date & $\begin{array}{r}\text { Mean SD } \\
(\mathrm{m})\end{array}$ & $\begin{array}{r}\text { Max SD } \\
(\mathrm{m})\end{array}$ & $\begin{array}{r}\text { SCA } \\
(\%)\end{array}$ & $\mathrm{CV}$ \\
\hline \multirow{6}{*}{$2011 / 12$} & $22 \mathrm{Feb}$ & 0.46 & 5.53 & 67.2 & 1.35 \\
\hline & $2 \mathrm{Apr}$ & 0.17 & 3.86 & 33.5 & 2.23 \\
\hline & $17 \mathrm{Apr}$ & 0.56 & 5.34 & 94.1 & 1.07 \\
\hline & 2 May & 0.90 & 6.11 & 98.8 & 0.74 \\
\hline & 14 May & 0.21 & 4.47 & 30.9 & 1.90 \\
\hline & 24 May & 0.09 & 4.32 & 18.9 & 1.29 \\
\hline \multirow{6}{*}{$2012 / 13$} & $17 \mathrm{Feb}$ & 2.91 & 10.89 & 98.8 & 0.63 \\
\hline & $3 \mathrm{Apr}$ & 3.19 & 11.20 & 100 & 0.56 \\
\hline & $25 \mathrm{Apr}$ & 2.42 & 10.10 & 96.3 & 0.76 \\
\hline & 6 Jun & 1.98 & 9.64 & 86.4 & 0.86 \\
\hline & 12 Jun & 1.69 & 8.90 & 77.1 & 0.90 \\
\hline & 20 Jun & 0.76 & 7.97 & 67.0 & 1.35 \\
\hline \multirow{4}{*}{$2013 / 14$} & $3 \mathrm{Feb}$ & 2.16 & 10.20 & 96.0 & 0.59 \\
\hline & $22 \mathrm{Feb}$ & 2.56 & 10.47 & 98.6 & 0.57 \\
\hline & 9 Apr & 2.54 & 9.72 & 89.0 & 0.65 \\
\hline & 5 May & 1.67 & 9.02 & 75.2 & 0.87 \\
\hline \multirow{4}{*}{$2014 / 15$} & $6 \mathrm{Nov}$ & 0.22 & 2.78 & 85.0 & 0.81 \\
\hline & 26 Jan & 0.74 & 4.88 & 89.3 & 0.85 \\
\hline & $6 \mathrm{Mar}$ & 2.13 & 11.55 & 94.0 & 0.69 \\
\hline & 12 May & 0.67 & 7.75 & 56.0 & 1.21 \\
\hline \multirow{3}{*}{$2015 / 16$} & $4 \mathrm{Feb}$ & 0.82 & 6.20 & 91.1 & 0.63 \\
\hline & $25 \mathrm{Apr}$ & 1.86 & 10.82 & 97.0 & 0.50 \\
\hline & 26 May & 1.16 & 7.81 & 74.8 & 0.70 \\
\hline \multirow{2}{*}{$2016 / 17$} & $20 \mathrm{Jan}$ & 1.26 & 6.33 & 93 & 0.72 \\
\hline & 8 May & 0.77 & 7.25 & 57.2 & 0.81 \\
\hline
\end{tabular}

for dates on which the snow cover had already completely melted over wide areas of the catchment.

Table 8 presents the average snow depth and the maximum snow depth value observed for each TLS acquisition. This table also shows the coefficient of variation on each snow distribution map and the fraction of the SCA. The values obtained depict the heavy accumulation of snow in some areas of the catchment, while the average snow depth is lower.

\subsection{Snow-covered area from time-lapse photographs}

The Izas Experimental Catchment is also equipped with a Campbell CC640 digital camera (Campbell Scientific Ltd, 2010). This camera was mounted on a solid metal structure set into the ground with concrete (Fig. 2), which ensured a constant position to obtain consistent information. The digital camera has a resolution of $640 \times 480$ pixels with a focal length of $6-12 \mathrm{~mm}$. The field of view of the photographs obtained with the camera mounted on the metal structure covers approximately 30 ha (Fig. 1), which repre- 

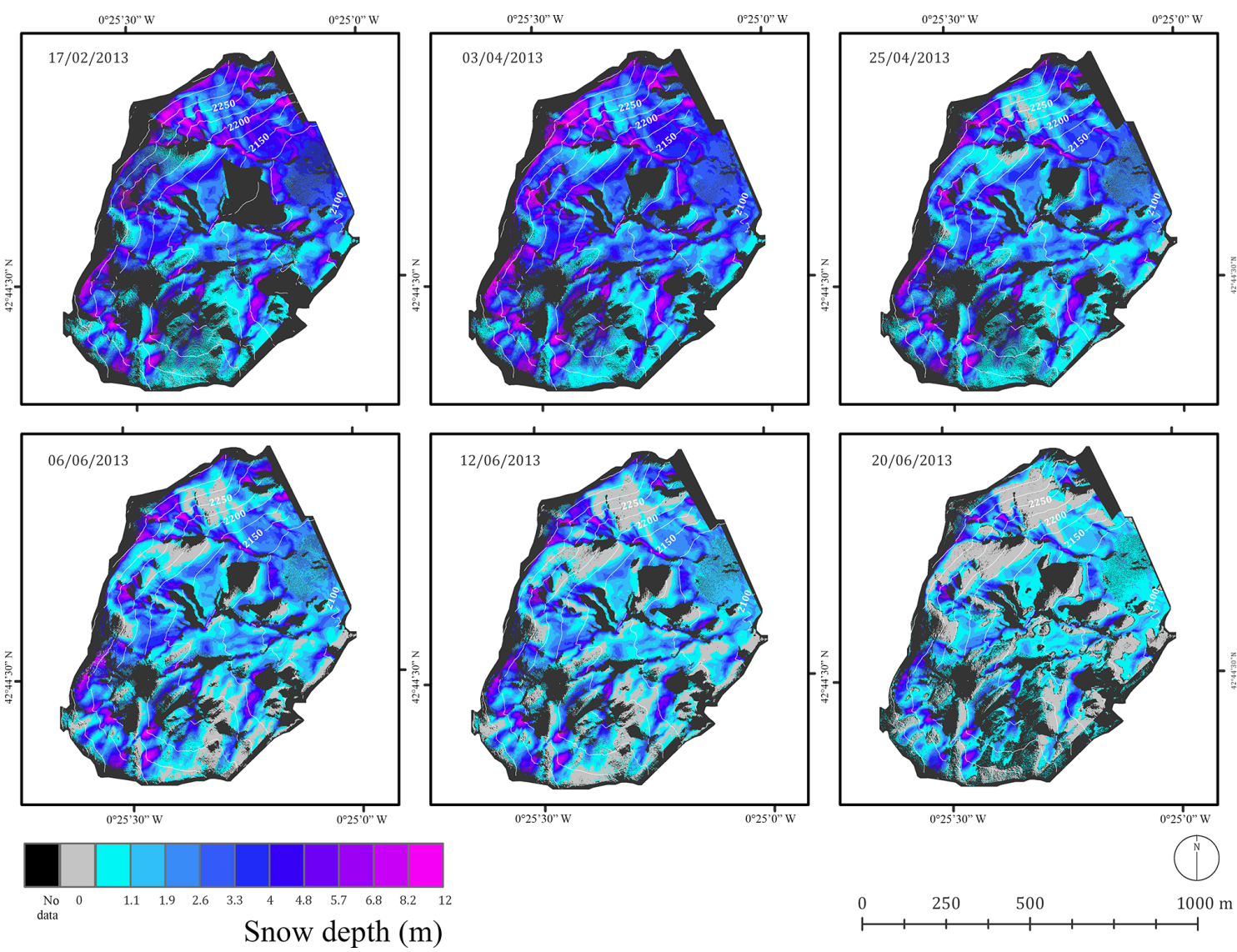

Figure 5. Snow depth distribution maps obtained for the six TLS acquisition dates of the 2012/13 snow season.

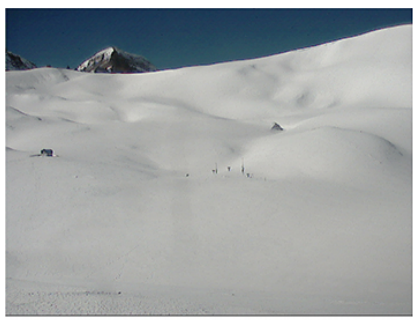

$22 / 02 / 2013$

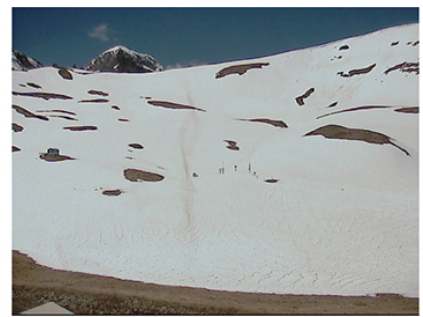

$13 / 05 / 2013$

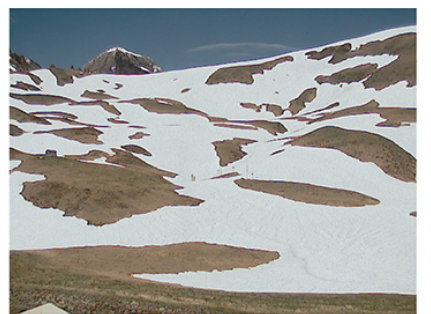

$22 / 06 / 2013$

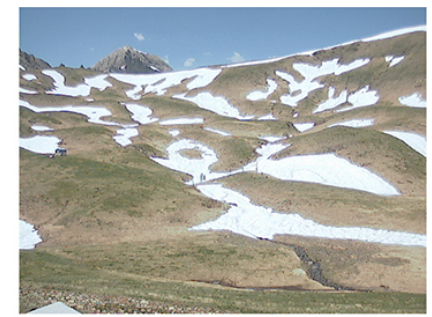

06/07/2013

Figure 6. Example of a sequence of four photographs for the 2012/13 snow season, showing the evolution of the snow cover.

sents about $52 \%$ of the total surface covered by the TLS. The camera obtained three pictures per day (time-lapse photography) at 10:00, 11:00 and 12:00 UTC, ensuring good illumination of the area. Figure 6 contains four photographs from the 2012/13 snow season, showing how the SCA evolved in time.

The pictures can be projected into a digital elevation model (DEM) of the study site. Projecting the pictures into the $1 \mathrm{~m} \times 1 \mathrm{~m}$ DEM for an entire snow season provides distributed information on the evolution of the SCA in the same reference system as snow depth maps. The approach for projecting the pictures into the DEM is described by Corri- pio (2004) and the specific features of the methodology applied in the Izas Experimental Catchment are fully described in Revuelto et al. (2016a). The routines applied first make a viewing transformation allowing for the optics of the camera and, second, a perspective projection, providing a virtual image of the DEM. Therefore, in the second step, the correspondence of ground control points with the pixels of the photograph must be established. Since this stage is quite sensitive, the coordinates of ground control points were acquired with a differential GPS. With this process, images projected into the DEM had a 3.3 pixel performance in the calibration of the transformation. Finally, the daily series of the projected im- 


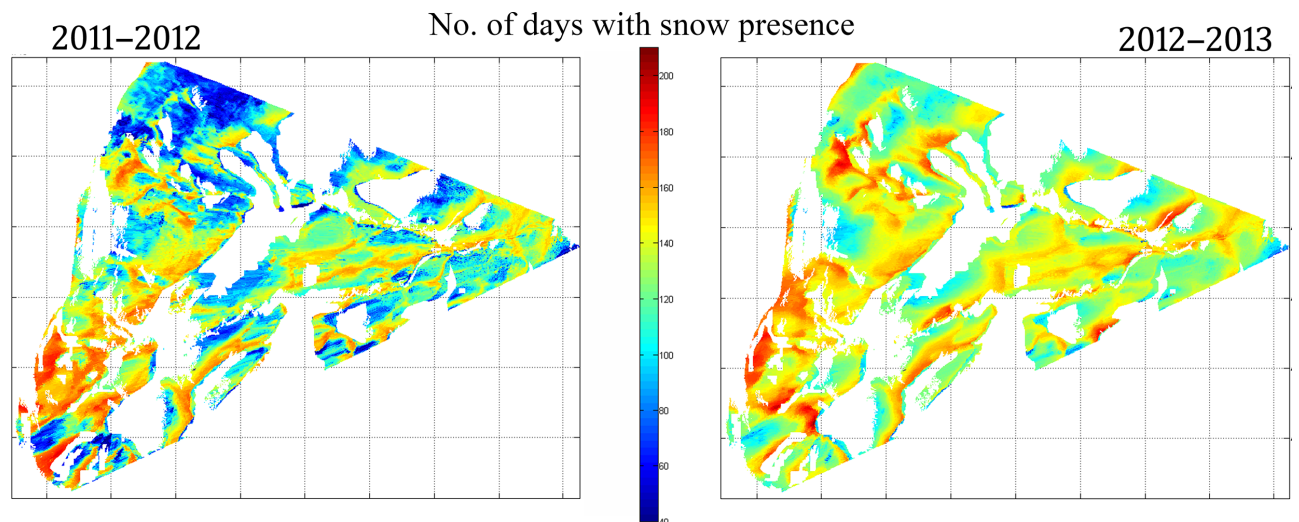

Figure 7. Number of days with snow present for each pixel for 2011/12 and 2012/13 snow seasons.

ages can be binarized to create daily snow presence-absence maps. This information can also be used for other applications, such as to observe the growth timing of plant species.

Since the binarized snow presence-absence maps were recorded on almost a daily frequency (note that about $20 \%$ of all photographs from the camera had to be discarded because cloud or snow obscured the camera lens), many parameters can be derived from this information, including the SCA temporal evolution, the numbers of days with snow presence or the melt-out date (MOD) on each pixel. Figure 7 shows an example of the number of days with snow presence for the 2011/12 and 2012/13 snow seasons.

\section{Data availability}

The database presented and described in this article is available for download at Zenodo (Revuelto et al., 2017; https://doi.org/10.5281/zenodo.848277). Meteorological data of the AWS are given in .csv format. The meteorological data set includes observations at $10 \mathrm{~min}$ intervals. The TLS survey snow depth distribution maps are available online (one file for each TLS acquisition). These files are in ASCII format in the UTM 30T north coordinate system with a $1 \mathrm{~m} \times 1 \mathrm{~m}$ spatial resolution. The DEM of the study area is also provided in same coordinate system. Photographs of cloud-free days from the time-lapse camera are available in the online repository, with the correspondence of pixel ground control points to GPS coordinates. Information on the optics and chip size of the camera is also provided. Additionally, all available MOD distribution maps (last Julian day with snow presence on each pixel) are included in the database.

\section{Summary}

The Izas Experimental Catchment is a well-established study area on the south face of the Pyrenees, in which different meteorological and snow variables are automatically acquired.
Additionally, great effort has been made on field data acquisition with TLS over the last five snow seasons and is ongoing. The data set described here is novel in the Pyrenees because, for the first time, it represents high-spatialresolution information on the snowpack distribution and its evolution in time, as well as making continuous information available on meteorological variables. The high quality of the information obtained has already been exploited for different studies on the understanding of snowpack dynamics and the improvement of simulation approaches to snowpack evolution in mountain areas (López-Moreno et al., 2012, 2014, Revuelto et al., 2014b, 2016a, 2016b). However, many scientific questions still go unanswered, such as the long-term influence of topography on snow dynamics, and the spatial distribution of snow during precipitation and strong wind events. Also, the high interannual variability in snow accumulation in the Pyrenees has serious consequences for water management, especially in the Mediterranean area (GarcíaRuiz et al., 2011). Thus, it is very important to continue obtaining information on snowpack evolution and the meteorological variables controlling snow dynamics. This information will allow the scientific community to better understand processes involved in snow dynamics and make for better adaptation to climate change scenarios. Moreover, offering the possibility of exploiting the information to other fields provides, as INARCH does, the opportunity of establishing new collaboration networks to push forward the frontiers of science in mountain areas.

Competing interests. The authors declare that they have no conflict of interest.

Special issue statement. This article is part of the special issue "Hydrometeorological data from mountain and alpine research catchments". It is not associated with a conference. 
Acknowledgements. This study was funded by the research projects CGL2014-52599-P "Estudio del manto de nieve en la montaña española y su respuesta a la variabilidad y cambio climatico" (Ministry of Economy and Development, MINECO) and CLIMPY "Characterization of the evolution of climate and provision of information for adaptation in the Pyrenees" (FEDER-POCTEFA). The authors are thankful for this unique opportunity to share information through the International Network for Alpine Research Catchment Hydrology (INARCH). Jesús Revuelto is supported by a postdoctoral Fellowship from the AXA research fund 2016 (le Post-Doctorant Jesús Revuelto est bénéficiaire d'une bourse postdoctorale du Fonds AXA pour la Recherche). Cesar AzorinMolina is supported by the Marie Skłodowska-Curie Individual Fellowship (STILLING project - 703733) funded by the European Commission.

Edited by: John Pomeroy

Reviewed by: two anonymous referees

\section{References}

ADCON Telemetry Company: Adcon BP1 Barometric Pressure Sensor, Copyright $\left({ }^{2} 2017\right.$ Adcon Telemetry, OTT Hydromet $\mathrm{GmbH}$, Klosterneuburg, Austria, 2017.

Alvera, B. and Garcia-Ruiz, J. M.: Variability of Sediment Yield from a High Mountain Catchment, Central Spanish Pyrenees, Arct. Antarct. Alp. Res., 32, 478-484, 2000.

Anderton, S. P., White, S. M., and Alvera, B.: Evaluation of spatial variability in snow water equivalent for a high mountain catchment, Hydrol. Process., 18, 435-453, 2004.

Azorin-Molina, C., Tijm, S., Ebert, E. E., Vicente-Serrano, S.-M., and Estrela, M.-J.: High Resolution HIRLAM Simulations of the Role of Low-Level Sea-Breeze Convergence in Initiating Deep Moist Convection in the Eastern Iberian Peninsula, Bound.-Lay. Meteorol., 154, 81-100, 2015.

Barnett, T. P., Adam, J. C., and Lettenmaier, D. P.: Potential impacts of a warming climate on water availability in snow-dominated regions, Nature, 438, 303-309, 2005.

Campbell Scientific Ltd: CC640 Digital Camera, Instruction Manual, Copyright () 2005-2010 Campbell Scientific Ltd, Campbell Park, Shepshed, Loughborough, UK, 2010.

Campbell Scientific Ltd: SR50A Sonic Ranging Sensor, User Guide, Copyright (C) 2007-2011 Campbell Scientific Ltd, Campbell Park, Shepshed, Loughborough, UK, 2011.

Campbell Scientific Ltd: 107 temperature Probe, User Guide, Copyright (C) 2003-2012 Campbell Scientific Ltd, Campbell Park, Shepshed, Loughborough, UK, 2012.

Campbell Scientific Ltd: IR100/IR120 Infra-red remote temperature sensor, User Guide, Copyright (C) 2007-2015 Campbell Scientific Ltd., Campbell Park, Shepshed, Loughborough, UK, 2015.

Chueca, J.: Geomorfología de la Alta Ribagorza: análisis de la dinámica de procesos en el ámbito superficial, Asoc. Guayente, Benasque, Spain, 1993.

Colbeck, S. C., Anderson, E. A., Bissell, V. C., Crock, A. G., Male, D. H., Slaughter, C. W., and Wiesnet, D. R.: Snow accumulation, distribution, melt, and runoff, Eos T. Am. Geophys. Un., 60, 465468, 1979.

Corripio, J. G.: Snow surface albedo estimation using terrestrial photography, Int. J. Remote Sens. 25, 5705-5729, 2004.
Creus-Novau, J.: El clima del alto Aragón occidental, CSIC - Instituto de Estudios Pirenaicos, Publicada con los Patrocinios de la Excma, Diputación Provincial de Huesca y la General de Aragón, 109, 233 pp., 1983.

Cuadrat, J. M., Saz, M. A., and Vicente-Serrano, S. M.: Atlas climático de Aragón, Gobierno de Aragón, 2007.

del Barrio, G., Creus, J., and Puigdefabregas, J.: Thermal Seasonality of the High Mountain Belts of the Pyrenees, Mt. Res. Dev. 10, 227-233, 1990.

del Barrio, G., Alvera, B., Puigdefabregas, J., and Diez, C.: Response of high mountain landscape to topographic variables: Central pyrenees, Landscape Ecol., 12, 95-115, 1997.

García-Ruiz, J. M., Puigdefabregas-Tomas, J., and Creus-Novau, J.: Snowpack accumulation in the Central Pyrenees, and its hydrological effects, Pirineos, 127, 27-72, 1986.

García-Ruiz, J. M., Beguería, S., López-Moreno, J. I., Lorente, A., and Seeger, M.: Los recursos hídricos superficiales del Pirineo aragonés y su evolución reciente, Geofroma Logroño, 2001.

García-Ruiz, J. M., López-Moreno, J. I., Vicente-Serrano, S. M., Lasanta-Martínez, T., and Beguería, S.: Mediterranean water resources in a global change scenario, Earth-Sci. Rev., 105, 121139, 2011.

Geonor A/S: Geonor T-200B series, All-weather precipitation gauges specifications, (C) 2010 Geonor A/S, Oslo, Norway, 2010.

Kipp \& Zonen B.V.: CMP/CMA series pyranometer and albedometer, Instruction Manual, Copyright (C 2016 Kipp \& Zonen B.V., Delft, the Netherlands, 2016.

Lana-Renault, N., Alvera, B., and García-Ruiz, J. M.: Runoff and Sediment Transport during the Snowmelt Period in a Mediterranean High-Mountain Catchment, Arct. Antarct. Alp. Res., 43, 213-222, 2011.

Liston, G. E.: Interrelationships among Snow Distribution, Snowmelt, and Snow Cover Depletion: Implications for Atmospheric, Hydrologic, and Ecologic Modeling, J. Appl. Meteorol., 38, 1474-1487, 1999.

López-Moreno, J. I.: Cambio ambiental y gestión de los embalses en el Pirineo Central Español, Consejo de Protección de la Naturaleza de Aragón, 2005.

López-Moreno, J. I. and García-Ruiz, J. M.: Influence of snow accumulation and snowmelt on streamflow in the central Spanish Pyrenees/Influence de l'accumulation et de la fonte de la neige sur les écoulements dans les Pyrénées centrales espagnoles, Hydrolog. Sci. J., 49, 787-802, 2004.

López-Moreno, J. I. and Nogués-Bravo, D.: Interpolating local snow depth data: an evaluation of methods, Hydrol. Process., 20, 2217-2232, 2006.

López-Moreno, J. I. and Vicente-Serrano, S. M.: Atmospheric circulation influence on the interannual variability of snow pack in the Spanish Pyrenees during the second half of the 20th century, Nord. Hydrol., 38, 33-44, 2007.

López-Moreno, J. I., Beguería, S., and García-Ruiz, J. M.: Influence of the Yesa reservoir on floods of the Aragón River, central Spanish Pyrenees, Hydrol. Earth Syst. Sci., 6, 753-762, https://doi.org/10.5194/hess-6-753-2002, 2002.

López-Moreno, J. I., Beniston, M., and García-Ruiz, J. M.: Environmental change and water management in the Pyrenees: Facts and future perspectives for Mediterranean mountains, Global Planet. Change, 61, 300-312, 2008. 
López-Moreno, J. I., Latron, J., and Lehmann, A.: Effects of sample and grid size on the accuracy and stability of regression-based snow interpolation methods, Hydrol. Process., 24, 1914-1928, 2010.

López-Moreno, J. I., Pomeroy, J. W., Revuelto, J., and VicenteSerrano, S. M.: Response of snow processes to climate change: spatial variability in a small basin in the Spanish Pyrenees, Hydrol. Process., 27, 2637-2650, 2012.

López-Moreno, J. I., Revuelto, J., Fassnacht, S. R., Azorín-Molina, C., Vicente-Serrano, S. M., Morán-Tejeda, E., and Sexstone, G. A.: Snowpack variability across various spatio-temporal resolutions, Hydrol. Process., 29, 1213-1224, 2014.

López-Moreno, J. I., Revuelto, J., Rico, I., Chueca-Cía, J., Julián, A., Serreta, A., Serrano, E., Vicente-Serrano, S. M., AzorinMolina, C., Alonso-González, E., and García-Ruiz, J. M.: Thinning of the Monte Perdido Glacier in the Spanish Pyrenees since 1981, The Cryosphere, 10, 681-694, https://doi.org/10.5194/tc10-681-2016, 2016.

Navarro-Serrano, F. M. and López-Moreno, J. I.: Spatio-temporal analysis of snowfall events in the spanish Pyrenees and their relationship to atmospheric circulation, Cuad. Investig. Geográfica, 43, 233-254, 2017.

Prokop, A.: Assessing the applicability of terrestrial laser scanning for spatial snow depth measurements, Cold Reg. Sci. Technol., 54, 155-163, 2008.

Revuelto, J., López-Moreno, J. I., Morán-Tejeda, E., Fassnacht, S.R., and Vicente-Serrano, S. M.: Variabilidad interanual del manto de nieve en el Pirineo: Tendencias observadas y su relación con índices de telconexión durante el periodo 19852011, Universidad de Salamanca, Salamanca, Spain, 613-621, 2012.

Revuelto, J., López-Moreno, J. I., Azorin-Molina, C., Zabalza, J., Arguedas, G., and Vicente-Serrano, S. M.: Mapping the annual evolution of snow depth in a small catchment in the Pyrenees using the long-range terrestrial laser scanning, J. Maps, 10, 1$15,2014 \mathrm{a}$.

Revuelto, J., López-Moreno, J. I., Azorin-Molina, C., and VicenteSerrano, S. M.: Topographic control of snowpack distribution in a small catchment in the central Spanish Pyrenees: intraand inter-annual persistence, The Cryosphere, 8, 1989-2006, https://doi.org/10.5194/tc-8-1989-2014, 2014b.
Revuelto, J., Jonas, T., and López-Moreno, J.-I.: Backward snow depth reconstruction at high spatial resolution based on timelapse photography, Hydrol. Process., 30, 2976-2990, 2016 a.

Revuelto, J., Vionnet, V., López-Moreno, J. I., Lafaysse, M., and Morin, S.: Combining snowpack modeling and terrestrial laser scanner observations improves the simulation of small scale snow dynamics, J. Hydrol., 291-307, 2016b.

Revuelto, J., Azorin-Molina, C., Alonso-González, E., SanmiguelVallelado, A., Navarro-Serrano, F., Rico, I., and LópezMoreno, J. I.: Observations of snowpack distribution and meteorological variables at the Izas Experimental Catchment (Spanish Pyrenees) from 2011 to 2017 [Data set], Zenodo, https://doi.org/10.5281/zenodo.848277, 2017.

RIEGL Laser Measurements: LPM-321, Long Range Laser Profil Measrurement System, (C) RIEGL, Horn, Austria, 2010.

Serrano, E., Agudo, C., Delaloyé, R., and González-Trueba, J. J.: Permafrost distribution in the Posets massif, Central Pyrenees, Norsk Geogr. Tidsskr., 55, 245-252, 2001.

Vaisala Company: HMP155 Humidity and Temperature Probe, specifications, (C) Vaisala 2012, Ref. B21072EN-E, 2012.

Vicente-Serrano, S. M.: Las sequías climáticas en el valle medio del Ebro: Factores atmosféricos, evolución temporal y variabilidad espacial, Consejo de Protección de la Naturaleza de Aragón, 2005.

Vicente-Serrano, S. M.: Spatial and temporal analysis of droughts in the Iberian Peninsula (1910-2000), Hydrolog. Sci. J., 51, 83-97, 2006.

Viviroli, D., Dürr, H. H., Messerli, B., Meybeck, M., and Weingartner, R.: Mountains of the world, water towers for humanity: Typology, mapping, and global significance, Water Resour. Res. 43, W07447, https://doi.org/10.1029/2006WR005653, 2007.

Wipf, S., Stoeckli, V., and Bebi, P.: Winter climate change in alpine tundra: plant responses to changes in snow depth and snowmelt timing, Climatic Change, 94, 105-121, 2009.

Young Company: Model 05103-45-5, Wind Monitor - Alpine Model, specifications, Copyright (C) 2010 R.M. Young Company, R.M. Young Company, Traverse City, Michigan, USA, 2010. 